\title{
THE EFFECT OF ENVIRONMENTAL DYNAMICS, MANAGEMENT CAPABILITIES AND BUSINESS STRATEGIES ON THE PERFORMANCE OF SASIRANGAN SMALL AND MEDIUM INDUSTRIES IN SOUTH KALIMANTAN PROVINCE
}

\author{
Maskur*, Zainul Mohammad \\ Department of Management, Islamic University of Muhammad Arsyad Al Banjari Kalimantan, \\ Banjarmasin, South Kalimantan, Indonesia \\ *E-mail: maskursariman@yahoo.co.id
}

\begin{abstract}
This study aims to examine the direct influence of environmental dynamics, management capabilities business strategies on the performance of small and medium industries. The study was applied to the Sasirangan Small and Medium Industry (SMI) sector in South Kalimantan. The method used was a quantitative approach because the data obtained from the survey results was in the form of numbers analyzed using statistics to answer questions and test the research hypotheses. The sample consisted of 83 respondents spread in three regencies/cities in South Kalimantan; they were owners or managers of the Sasirangan SMI. They were determined by the purposive sampling technique. Data collection was done through observations, questionnaires, and direct interviews. Secondary data was obtained from the Provincial Government of South Kalimantan and related agencies. The data analysis involved Generalized Structured Component Analysis. The results of hypothesis testing show that environmental dynamics, management capabilities, and business strategies have a direct and positive effect on the performance of SMls. The good environmental dynamics encourages better performance of SMls, the management capabilities of the SMI owners can directly improve the performance of SMls, and the implementation of the business strategy carried out by SMls can improve the performance of SMls.
\end{abstract}

\section{KEY WORDS}

Environmental dynamics, management capabilities, business strategies, SMI performance.

Globalization has made business environment (external factors) as a determinant for the competitive advantage of a company. The environment is seen as a dynamic whose changes are difficult to predict, yet can create opportunities as well as challenges for the company (Miles et al., 2000; Hashim et al., 2001; Nandakumar et al., 2010; Bastian and Muchlish, 2012; Mohd et al., 2013). Thus, the survival and success of a company depends on the ability to monitor and adapt to its business environment. According to Hashim et al. (2001), power outside the company that affects performance is included in the dynamism variable, which identifies the uncertainty of environment. Environmental influences, in addition to uncertainty, can also be in the form of intensity of competition referred to as the hostility variable (Hashim et al., 2001).

The business environment has a strong influence on the organization of the company, especially when the world of business is a borderless world; the change of hard technology to smart technology and other fundamental changes affect the policies that will be taken by the company management (Hunger, 2007; Brooks, 1997; Lumpkin, 2005).

Facing increasingly fierce industrial competition due to changes in the business environment has been forcing industries, both in the manufacturing and service industries, to think of new ways to win the competition. The development of small and medium industries (SMIs) in regional and global markets must be based on continuous efforts to make them a strong business; the role of SMls cannot be underestimated because they are a determining factor of most of the world economy (Storey, 1994).

Changes in the business environment require specific ways to deal with because most of these changes are beyond the control of the company (Efferin and Handrian, 2010) and 
can bring both opportunities and threats to the company (Lawrence and Weber, 2010; Efferin and Soeherman, 2010). For companies that can dynamically utilize the changes as a new opportunity, the company will benefit, but on the contrary, for companies that tend to be static, changes will become a threat to survival. This external environment alone will give reciprocal influence to each other (Brooks and Weatherston, 2000; Lawrence and Weber, 2010). The survival and success of a company depends on the ability to monitor and adapt to its business environment (Boyd and Fulk, 1996), to guide business strategies to realize the achievement of business objectives effectively (Bisbea and Malagueno, 2012).

A business environment that focuses on environmental dynamics can be conceptualized as a rapidly changing and discontinuous environment in demands, market, competitor, technology, and regulation, so information is often inaccurate or unavailable (Bastian and Muchlish, 2012). Furthermore, Hashim et al. (2001) identify the existence of environmental uncertainty and high intensity of competition that environmental dynamics encourages companies to behave as entrepreneurs. Mohd et al. (2013) argue that the external environment has a direct effect on the performance of the company without looking at the choices of the strategies carried out by the company; this can mean that the external environment can hinder and or directly support performance. Research conducted by Isabela and Waddock (1994) confirms a positive relationship between organizational performance and environmental dynamics. Bastian and Muchlish (2012) suggest that the results of research in manufacturing companies show a significant influence of environmental uncertainty on business performance. This is also in line with research conducted by Purnomo and Subroto (2016), which shows that a significant influence of environmental uncertainty on business performance. Entrepreneurial orientation and business strategies have a significant effect on company performance. Entrepreneurial orientation of Sasirangan SMI owners has been proven to be able to support business strategies; this means that entrepreneurial orientation directly affects the implementation of business strategies (Maskur, 2018).

Miles et al. (2000) and Azadegan et al. (2013) state different opinions that there is no evidence of the direct influence of external environment on company performance. This gap provides an opportunity to examine the direct effect of environmental dynamics on the performance of SMls.

Based on findings from previous studies, environmental dynamics have a close correlation with the performance of small and medium industries. Therefore, it is necessary to further test the relationship.

Tidd and Pavitt (1998) state that management capability is very important in small, medium, and large-scale industries, where each requires management activities to coordinate the capabilities or skills of the workers and the coordination of resources. The role of leaders or owners of the company to understand and carry out management functions is crucial to achieve the success of a business. Peters (1998) states that during the growth phase, a leader or manager requires management skills to develop a business.

Management skills by an entrepreneur are used to manage the company in terms of marketing, production, finance, and human resources. Ansoff (1990) reveals the ability of a business to include the ability to make plans, determine priorities or strategies, and correct strategies. Furthermore, Edward (1994) states that the level of business ability is related to the way one formulates the company's functional policy to determine the strategic actions to be taken. According to Wai and Kuan (2011), solid management is the key to success. However, small and medium industries sometimes face difficulties in developing the management skills needed to survive in a complex environment.

The results of the empirical study show that most SMI owners do not have management skills because of the low educational background. According to Suci (2009), most IKM owners rely on experience and knowledge from parents. In general, is only for the short term and the majority of businesses are run simply for owners or workers to earn for their daily needs.

Some results of empirical studies confirm that management capabilities have a significant effect on business performance in small and manufacturing industries (Chi et al., 
2011; Wai and Kuan, 2011; Dani et al., 2013; Fening, 2012). This is confirmed by Chi et al. (2011) explaining that management ability if supported by good knowledge will improve the performance of small and manufacturing businesses. There are several gaps from previous studies-some confirm that management skills are not significant for business performance (Nurhayati, 2004; Suci, 2009; Nur, 2014; Urisc and Mulej, 2005), while others confirm that management skills have a positive and significant influence on business performance (Mokros, 2007; Latief, 2008; Yahya et al., 2010; Mahmud, 2011). Thus, further studies to examine the effect of management capabilities on performance of small and medium industries must be carried out.

The literature study of strategic planning and performance shows that companies proactively investing time in developing strategies have higher levels of performance than companies that are proactive but do not develop strategies (Covin and Slevin, 1991). In line with this, Jiao et al. (2013) explain that the superior position in competition can be realized if the company is able to capture the opportunities offered by the business environment; in other words, it can reduce the impact of threats through the formulation of strategies, and then use them as a strong foundation to implement strategies. Surachman (2002) further explains that the analysis and diagnosis of a company's external environment must be done synergistically, as well as be used as input in the preparation of strategies to create sustainable performance. Porter (2005) explains that the concept of contingency emphasizes alignment of strategies with the business environment as a determinant of survival or performance of a company.

Zhi and Jintong (2012) argue that companies implementing business strategies in their business activities will be able to overcome the business uncertainty. The results of this empirical study also confirm that business strategies have a significant effect on the performance of small and medium enterprises (Parnell, 2010; Hashim et al., 2001; Mohd et al., 2013; Hsu, 2012; Li and Tan, 2013); yet, Xiaoying et al. (2008), Zhi and Jintong (2012) have found that business strategies have no significant effect on performance.

The different results of the previous studies have motivated the researcher to further test whether business strategies have an influence on the performance of small and medium industries.

\section{CONCEPTUAL FRAMEWORK}

Hashim et al. (2001) explore the role of business strategies on performance and produce a contingency alternative model. The model proposed by Hashim et al. (2001) offers a mediating role from environmental factors in the relationship of business strategies and performance, as well as the role of business strategies that directly affect performance. In the present study, the model shows the role of environmental dynamics as an independent variable directly affecting the performance of SMls. Based on these findings, the researcher examines the effect of environmental dynamics on performance of SMls, which simultaneously compares the findings of previous studies, especially Hashim et al. (2001) in small and medium enterprises in Malaysia.

In addition, this study will also examine the effect of management capabilities as investigated by Chi et al. (2011) and Wai and Kuan (2011) on performance. This study is the synergy of the previous conceptual framework by Hasihim et al. (2001), Miles et al. (2000), Nandakumar et al. (2010), Bastian and Muchlish (2012), which examined the dimensions of environmental dynamics and strategies for performance, as well as the research by Wai and Kuan (2011), Chi et al. (2011), and Dani et al. (2013) about the influence of management capabilities on business performance.

The existing models are the basis for the formation of a conceptual framework; yet not all models are fully adopted. This study will test and explain the influence of environmental dynamics, management capabilities, and business strategies on performance of SMls. In accordance with the description on the background, theoretical basis, and previous research, the following conceptual framework is proposed. 


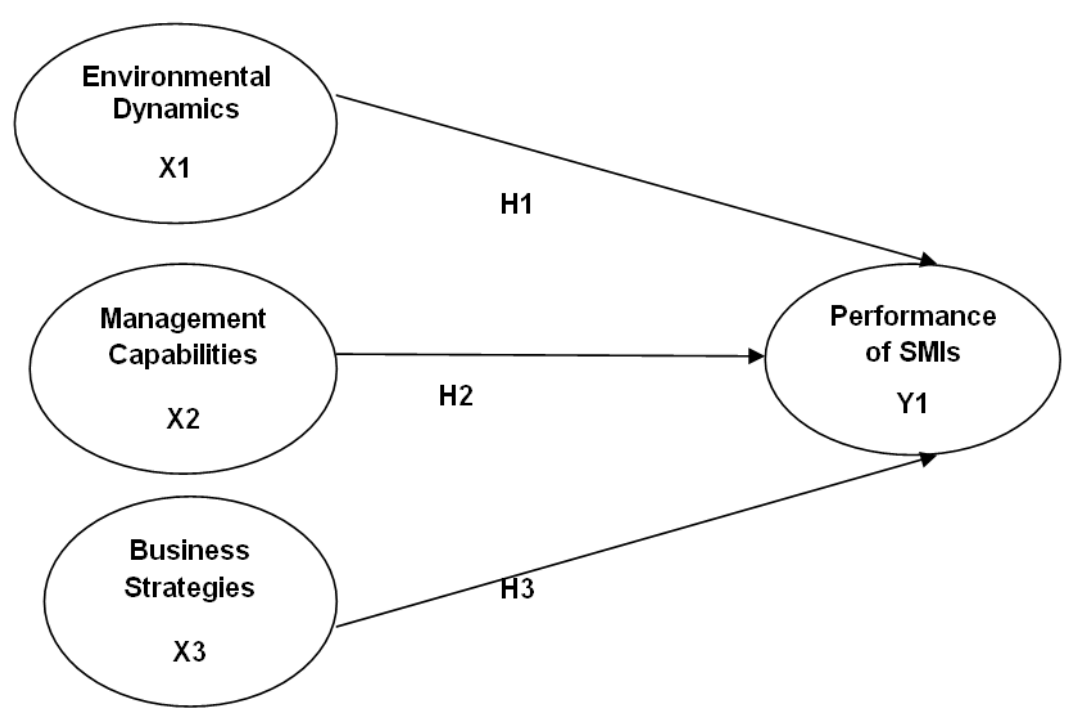

Figure 1 - The Conceptual Framework

Hypotheses:

$\mathrm{H} 1$ : Environmental dynamics affect performance of SMls;

$\mathrm{H} 2$ : Management capabilities affect performance of SMls;

H3: Business strategies affect performance of SMls.

\section{METHODS OF RESEARCH}

Study Sites. This study was conducted in three areas in South Kalimantan, namely Banjarmasin, Martapura, and Banjarbaru as they are the centers for SMls, are close to each other, and are home for many Sasirangan SMI owners compared to other regencies.

This study aims to examine the influence of environmental dynamics, management capabilities, and business strategies on the performance of SMls. The study is explanatory research, a kind of study conducted by identifying facts or events that arise from the object under study, then an investigation to explain the phenomenon of problems based on the interaction of the variables under study is conducted (Sugiono, 2008). The analytical method used is Generalized Structured Component Analysis (GSCA). The study employed primary data and secondary data. Primary data was collected through questionnaires, interviews, and observations to respondents or managers of Sasirangan SMls, while secondary data was obtained through related agencies.

Research Design. The approach was a quantitative approach (positivism) because the data obtained from the survey in the form of numbers analyzed using statistics to answer questions and test hypotheses. The results of statistical tests are used to explain the position of the variables studied and predict the relationship of variables (Creswell, 2009). Table 1.

Population and Sample. The population and sample in this study is elaborated in

Table 1 - Population and Sample of Sasirangan SMls

\begin{tabular}{|l|l|l|l|}
\hline No & City/Regency & Population & Sample \\
\hline 1 & Banjarmasin & 48 & 48 \\
\hline 2 & Martapura & 29 & 29 \\
\hline 3 & Banjarbaru & 6 & 6 \\
\hline & Total & 83 & 83 \\
\hline
\end{tabular}

The population in this study was 83 owners of Sasirangan SMls in three cities/regencies of South Kalimantan. The data came from questionnaires distributed directly to all owners; these 83 owners were also samples in the study. 
Measurement Scale. Based on the operationalization of the research variables, the indicators cannot be measured directly (latent variables); the variables need to be translated into manifest variables. The measurement results are related to the analysis as to provide understanding of variables and interaction patterns. The measurement scale used in this study is a Likert scale. It generally involves scale points and degree of agreement. In this study, the alternatives were 1 to 5 , in which 1 means strongly disagree, 2 means disagree, 3 means neutral, 4 means agree, and 5 means strongly agree.

Validity Test. The validity measurement was done by doing bivariate correlation between each item score and total item score, with Pearson Correlation Coefficient. The test of item validity aims to find out the relationship between independent variables (constructs) to their proxy (indicators) by correlating the value of items with total values (Parsian and Dunning, 2009). Questions or statements are considered valid if the correlation coefficient $(r)$ is equal to or greater than 0.3 , because $r$ which is less than 0.3 represents small influence or a weak relationship (Cohen, 1992). If an indicator has items less than 30, then the benchmark for item validity is corrected $r$, with the following formula (Azwar, 2013):

$$
r_{i(x-i)}=\frac{r_{i x} S_{x}-S_{i}}{\sqrt{\left[S_{x}^{2}+S_{i}^{2}-2 r_{i x} S_{i} S_{x}\right]}}
$$

In which $r$ represents the Pearson Correlation Coefficient:

$$
\mathrm{r}_{\mathrm{ix}}=\frac{\mathrm{n} \Sigma \mathrm{ix}-\Sigma \mathrm{i} \Sigma \mathrm{x}}{\sqrt{\left(\mathrm{n} \Sigma \mathrm{i}^{2}-(\Sigma \mathrm{i})^{2}\right)\left(\mathrm{n} \Sigma \mathrm{x}^{2}-(\Sigma \mathrm{x})^{2}\right)}}
$$

The results of the validity test for each variable are completely presented in the following tables.

Table 2 - Validity Test Results on Indicators of Environmental Dynamics (X1)

\begin{tabular}{|c|c|c|c|c|}
\hline Indicators & Item & Corrected $r$ & Minimum Criteria & Note \\
\hline \multirow{4}{*}{ Environmental Uncertainty } & $\mathrm{X} 1.1 .1$ & 0.538 & 0.3 & Valid \\
\cline { 2 - 5 } & $\mathrm{X} 1.1 .2$ & 0.579 & 0.3 & Valid \\
\cline { 2 - 5 } & $\mathrm{X} 1.1 .3$ & 0.312 & 0.3 & Valid \\
\cline { 2 - 5 } & $\mathrm{X} 1.1 .4$ & 0.387 & 0.3 & Valid \\
\hline \multirow{3}{*}{ Intensity of Competition } & $\mathrm{X} 1.2 .1$ & 0.638 & 0.3 & Valid \\
\cline { 2 - 5 } & $\mathrm{X} 1.2 .2$ & 0.561 & 0.3 & Valid \\
\cline { 2 - 5 } & $\mathrm{X} 1.2 .3$ & 0.587 & 0.3 & Valid \\
\cline { 2 - 5 } & $\mathrm{X} 1.2 .4$ & 0.422 & 0.3 & Valid \\
\hline
\end{tabular}

Environmental dynamics (X1) consists of two (2) indicators and eight (8) items. All meet the minimum criteria of having corrected $r>0.3$. This means that all items are valid, thus all can be included in the research process.

The validity test results on the management capabilities are shown in Table 3.

Table 3 - Validity Test Results on Indicators of Management Capabilities (X2)

\begin{tabular}{|c|c|c|c|c|}
\hline Indicators & Item & Corrected r & Minimum Criteria & Note \\
\hline \multirow{2}{*}{ Planning. } & X2.1.1 & 0.489 & 0.3 & Valid \\
\cline { 2 - 5 } & $\mathrm{X} 2.1 .2$ & 0.489 & 0.3 & Valid \\
\hline \multirow{2}{*}{ Organizing } & $\mathrm{X} 2.2 .1$ & 0.484 & 0.3 & Valid \\
\cline { 2 - 5 } & $\mathrm{X} 2.2 .2$ & 0.484 & 0.3 & Valid \\
\hline \multirow{2}{*}{ Directing } & $\mathrm{X} 2.3 .1$ & 0.591 & 0.3 & Valid \\
\cline { 2 - 5 } & $\mathrm{X} 2.3 .2$ & 0.591 & 0.3 & Valid \\
\hline \multirow{2}{*}{ Monitoring } & $\mathrm{X} 2.4 .1$ & 0.556 & 0.3 & Valid \\
\cline { 2 - 5 } & $\mathrm{X} 2.4 .2$ & 0.556 & 0.3 & Valid \\
\hline
\end{tabular}

Management capabilities (X2) consist of four (4) indicators and eight (8) items. All meet the minimum criteria of having corrected $r>0.3$. This means that all items are valid, thus all can be included in the research process. 
The validity test results on the business strategies are shown in Table 4.

Table 4 - Validity Test Results on Indicators of Business Strategies (X3)

\begin{tabular}{|c|c|c|c|c|}
\hline Indicators & Item & Corrected $r$ & Minimum Criteria & Note \\
\hline \multirow{4}{*}{ Low Cost Strategy } & X3.1.1 & 0.538 & 0.3 & Valid \\
\cline { 2 - 5 } & X3.1.2 & 0.538 & 0.3 & Valid \\
\cline { 2 - 5 } & X3.1.3 & 0.071 & 0.3 & Not Valid \\
\cline { 2 - 5 } & X3.1.4 & 0.192 & 0.3 & Valid \\
\hline \multirow{4}{*}{ Differentiation Strategy } & X3.2.1 & 0.634 & 0.3 & Valid \\
\cline { 2 - 5 } & X3.2.2 & 0.710 & 0.3 & Valid \\
\cline { 2 - 5 } & X3.2.3 & 0.664 & 0.3 & Valid \\
\cline { 2 - 5 } & X3.2.4 & 0.438 & 0.3 & Valid \\
\hline \multirow{3}{*}{ Focus Strategy } & X3.1.1 & 0.454 & 0.3 & Valid \\
\cline { 2 - 5 } & X3.1.2 & 0.446 & 0.3 & Valid \\
\cline { 2 - 5 }
\end{tabular}

Business strategies (X3) consist of three (3) indicators and eleven (11) items. From the eleven (11) items, one did not meet the minimum criteria of having corrected $r>0.3$, i.e. the item was X3.1.3 (production cost efficiency) on the Y1.1 indicator (low cost strategy). This means that this one not-valid item is not included in the research process.

The validity test results on the performance of SMls are shown in Table 5.

Table 5 - Validity Test Results on Indicators of Performance (Y1)

\begin{tabular}{|c|c|c|c|c|}
\hline Indicators & Item & Corrected r & Minimum Criteria & Note \\
\hline \multirow{2}{*}{ Sales Growth } & Y1.1.1 & 0.703 & 0.3 & Valid \\
\cline { 2 - 5 } & $\mathrm{Y} 1.1 .2$ & 0.703 & 0.3 & Valid \\
\hline \multirow{2}{*}{ Profit Growth } & $\mathrm{Y} 1.2 .1$ & 0.581 & 0.3 & Valid \\
\cline { 2 - 5 } & $\mathrm{Y} 1.2 .2$ & 0.581 & 0.3 & Valid \\
\hline \multirow{2}{*}{ Capital Growth } & $\mathrm{Y} 1.3 .1$ & 0.468 & 0.3 & Valid \\
\cline { 2 - 5 } & $\mathrm{Y} 1.3 .2$ & 0.468 & 0.3 & Valid \\
\hline
\end{tabular}

Performance (Y1) consists of three (3) indicators and six (6) items. All meet the minimum criteria of having corrected $r>0.3$. This means that all items are valid, thus all can be included in the research process.

Table 6 - Reliability Test

\begin{tabular}{|c|c|c|c|}
\hline Variable & Indicators & Alpha & Note \\
\hline \multirow{2}{*}{$\begin{array}{l}\text { Environmental Dynamics } \\
(\mathrm{X} 1)\end{array}$} & Environmental Uncertainty (X1.1) & 0.716 & Reliable \\
\hline & Intensity of Competition (X1.2) & 0.744 & Reliable \\
\hline \multirow{4}{*}{$\begin{array}{c}\text { Management Capabilities } \\
\text { (X2) }\end{array}$} & Planning $(\mathrm{X} 2.1)$ & 0.656 & Reliable \\
\hline & Organizing (X2.2) & 0.638 & Reliable \\
\hline & Directing (X2.3) & 0.722 & Reliable \\
\hline & Monitoring (X2.4) & 0.677 & Reliable \\
\hline \multirow{3}{*}{ Business Strategies (X3) } & Low Cost Strategy (X3.1) & 0.633 & Reliable \\
\hline & Differentiation Strategy (X3.2) & 0.795 & Reliable \\
\hline & Focus Strategy (X3.3) & 0.893 & Reliable \\
\hline \multirow{3}{*}{ Performance (Y1) } & Sales Growth (Y1.1) & 0.824 & Reliable \\
\hline & Profit Growth (Y1.2) & 0.732 & Reliable \\
\hline & Capital Growth (Y1.3) & 0.622 & Reliable \\
\hline
\end{tabular}

Table 6 shows that all indicators have an Alpha Cronbach greater than 0.6 , so all variables are reliable and can be used as a data collection tool.

\section{RESULTS AND DISCUSSION}


Table 7 shows that owners are mostly male (44 people or $53 \%$ ), and the rest 39 people or $47 \%$ are female. The difference in number is not big; this shows that both male and female are suitable as entrepreneurs or owners of SMls, needing characteristics as a risk taker and being responsible (to employees and business). Therefore, the role of women in the future will be increasingly important as entrepreneurs in SMls, especially in the three regencies/cities in South Kalimantan. This finding is expected to inspire women to be an entrepreneur.

Table 7 - Description of Sasirangan SMI Owners Based on Sex

\begin{tabular}{|c|c|c|c|}
\hline No & Sex & Frequency & Percentage (\%) \\
\hline 1 & Male & 44 & 53 \\
\hline 2 & Female & 39 & 47 \\
\hline & Total & 83 & 100 \\
\hline
\end{tabular}

Table 8 - Description of Sasirangan SMI Owners Based on Residence

\begin{tabular}{|c|c|c|c|}
\hline No & Residence & Frequency & Percentage (\%) \\
\hline 1 & Banjarmasin & 48 & 57.83 \\
\hline 2 & Martapura & 29 & 34.94 \\
\hline 3 & Banjarbaru & 6 & 7.23 \\
\hline & Total & 83 & 100 \\
\hline
\end{tabular}

Table 8 shows that the majority of owners live in Banjarmasin (48 people or $57.8 \%$ ), then 29 people or $34.9 \%$ and 6 people or $7.2 \%$ live in Martapura and Banjarbaru. The finding shows that most Sasirangan SMls are in Banjarmasin, as the business was originally started there. In addition, Banjarmasin also has a strategic position for business because it is in the provincial capital. The other two locations, however, are not far from Banjarmasin.

Table 9 - Description of Sasirangan SMI Owners Based on Education

\begin{tabular}{|c|c|c|}
\hline Education & Frequency & Percentage (\%) \\
\hline Elementary & 8 & 9.6 \\
\hline Junior High & 27 & 32.5 \\
\hline Senior High & 37 & 44.6 \\
\hline Diploma & 2 & 2.4 \\
\hline S1 (under-graduate) & 7 & 8.4 \\
\hline S2 (post-graduate) & 2 & 2.4 \\
\hline Total & 83 & 100 \\
\hline
\end{tabular}

Table 9 shows that most ISM owners graduated senior high school (37 people or $44.6 \%$ ), junior high school (27 people or $32.5 \%$ ), elementary school (8 people or $9.6 \%$ ), while the remaining graduated a Diploma program (2 people or $2.4 \%$ ), S1 (7 people or $8.4 \%$ ), and S2 (2 people or $2 \%$ ). This illustrates that the majority of owners graduated high school and lower. Based on their position, as owners and managers, education is important for the development of their industry. The results of the interviews provide an overview of the need for education and training programs for SMI entrepreneurs to improve the ability and insight in managing a business.

Table 10 - Description of Sasirangan SMI Owners Based on Age

\begin{tabular}{|c|c|c|c|}
\hline Number & Age (Year) & Frequency & Percentage (\%) \\
\hline 1 & $\leq 30$ & 10 & 39.8 \\
\hline 2 & $31-40$ & 33 & 39.8 \\
\hline 3 & $41-50$ & 33 & 2.4 \\
\hline 4 & $51-60$ & 2 & 3.6 \\
\hline 5 & $61-70$ & 3 & 1.2 \\
\hline 6 & $71-80$ & 1 & 1.2 \\
\hline 7 & $>80$ & 1 & 100 \\
\hline
\end{tabular}

Table 10 shows that the most ISM owners are in the age range of 31 to 40 years (33 people or $39.8 \%$ ) and 41 to 50 years (33 people or $39.8 \%$ ). Only a small number of them are 
above 50 , in which 2 people or $2.4 \%$ are 51 to 60 years old, 3 people or $3.6 \%$ are 61 to 70 years old, 1 person or $1.2 \%$ are 71 to 80 years or more. In general, most owners are 31 and $50(79.6 \%)$; these people are the second generation continuing the family business and those who used to work as employees then open their own businesses. This shows that young generation is interested in developing the industry because it is one of the superior products of South Kalimantan.

Table 11 - Description of Sasirangan SMI Owners Business Age

\begin{tabular}{|c|c|c|c|}
\hline No & Business Age (Year) & Frequency & Percentage (\%) \\
\hline 1 & $\leq 5$ & 20 & 24.10 \\
\hline 2 & $6-10$ & 17 & 20.48 \\
\hline 3 & $11-15$ & 22 & 26.50 \\
\hline 4 & $16-20$ & 7 & 8.43 \\
\hline 5 & $21-25$ & 15 & 18.08 \\
\hline 6 & $>25$ & 2 & 2.41 \\
\hline & Total & 83 & 100 \\
\hline
\end{tabular}

Table 11 shows that most owners run the business for 5 years, 6 to 10 years, and 11 to 15 years (59 business or $71.08 \%$ ). This means that most of the Sasirangan SMI owners in South Kalimantan Province are relatively new. The business can be considered as mature because during that short period of time, owners have had the internal ability to be responsive and adaptive to the dynamic changes in the business environment.

Table 12 - Description of Sasirangan SMI Owners Business Workshop Status

\begin{tabular}{|c|c|c|c|}
\hline No & Business Workshop Status & Frequency & Percentage (\%) \\
\hline 1 & Personally Owned & 77 & 92.8 \\
\hline 2 & Rent & 6 & 7.2 \\
\hline & Total & 83 & 100 \\
\hline
\end{tabular}

Table 12 shows that most Sasirangan SMI owners already have their own workshop (77 people or $92.8 \%$ ). The remaining 6 people or $7.2 \%$ still rent a place to run their business. The results of data collection confirm that most owners already have a house, and they use their house as the workshop.

Table 11 - Description of Sasirangan SMI Employee Numbers

\begin{tabular}{|c|c|c|c|}
\hline No & Number of Employees & Frequency & Percentage (\%) \\
\hline 1 & $\leq 15$ & 45 & 54.2 \\
\hline 2 & $16-20$ & 35 & 42.2 \\
\hline 3 & $21-25$ & 0 & 0 \\
\hline 4 & $>25$ & 3 & 3.6 \\
\hline & Total & 83 & 100 \\
\hline
\end{tabular}

Table 12 shows 45 or $54.2 \%$ owners have around 15 employees, 35 or $42.2 \%$ owners have 16 to 20 employees, and 3 or $3.6 \%$ owners have more than 25 employees. The number of employees is determined by the size of the business. Sasirangan SMls are classified as a labor-intensive industry because it requires a lot of labor and the production process is still done manually or handmade.

Table 13 - The Measurement Model for Environmental Uncertainty $\left(\mathrm{X}_{1.1}\right)$

\begin{tabular}{|c|c|c|c|c|c|c|}
\hline \multirow{2}{*}{ Item } & \multicolumn{3}{|l|}{ Loading } & \multicolumn{3}{|l|}{ Weight } \\
\hline & Estimate & SE & CR & Estimate & SE & CR \\
\hline $\mathrm{X}_{1.1 .1}$ & 0.817 & 0.010 & $85.09^{*}$ & 0.421 & 0.034 & $12.51^{*}$ \\
\hline$X_{1.1 .2}$ & 0.851 & 0.016 & $52.5^{*}$ & 0.469 & 0.048 & $9.79^{*}$ \\
\hline$X_{1.1 .3}$ & 0.654 & 0.012 & $54.5^{x}$ & 0.413 & 0.036 & $11.47^{*}$ \\
\hline $\mathrm{X}_{1.1 .4}$ & 0.723 & 0.118 & $6.12^{x}$ & 0.355 & 0.024 & $15.11^{*}$ \\
\hline
\end{tabular}

The indicators to measure the environmental dynamics are environmental uncertainty $\left(\mathbf{X}_{1.1}\right)$ and intensity of competition $\left(\mathbf{X}_{1.2}\right)$. Each indicator is developed into some items. 
The environmental uncertainty indicator (X1.1) is measured by 4 (four) items, namely newcomers can threaten sales volume in the market $\left(X_{1.1 .1}\right)$, products made by other companies become alternative choices for consumers $\left(X_{1.1 .2}\right)$, government regulations provide support for SMls $\left(\mathrm{X}_{1.1 .3}\right)$, and raw and supporting materials for industries often cause price and quality problems $\left(X_{1.1 .4}\right)$. The results of the measurement model for this indicator show all items are valid and significant at $\alpha 0.05$. The item "products made by other companies become an alternative choice for consumers $\left(X_{1.1 .2}\right)$ " has the highest factor loading of 0.851 ; thus, it is considered as the best representation of environmental uncertainty. The contribution of other items seen from the loading factor is newcomers $\left(X_{1.1 .1}\right)$ of 0.817 , materials $\left(X_{1.1 .4}\right)$ of 0.723 , and regulations $\left(X_{1.1 .3}\right)$ of 0.654 .

Table 14 - The Measurement Model for Intensity of Competition $\left(\mathrm{X}_{1.2}\right)$

\begin{tabular}{|c|c|c|c|c|c|c|}
\hline \multirow{2}{*}{ Item } & \multicolumn{3}{|c|}{ Loading } & \multicolumn{3}{c|}{ Weight } \\
\cline { 2 - 7 } & Estimate & SE & CR & Estimate & SE & CR \\
\hline $\mathrm{X}_{1.2 .1}$ & 0.823 & 0.025 & $33.12^{*}$ & 0.391 & 0.036 & $10.99^{*}$ \\
\hline $\mathrm{X}_{\text {.1.2.2 }}$ & 0.779 & 0.006 & $141.41^{*}$ & 0.329 & 0.009 & $36.48^{*}$ \\
\hline $\mathrm{X}_{\text {.1.2.3 }}$ & 0.760 & 0.052 & $14.5^{*}$ & 0.306 & 0.015 & $20.99^{*}$ \\
\hline $\mathrm{X}_{\text {.1.2.4 }}$ & 0.661 & 0.014 & $47.81^{*}$ & 0.289 & 0.002 & $125.4^{*}$ \\
\hline
\end{tabular}

The second indicator as to measure environmental dynamics (X1) is the of competition (X1.2) measured by using 4 (four) items, namely the tight competition on product quality among the Sasirangan industry $\left(\mathrm{X}_{1.2 .1}\right)$, various promotional strategies carried out by each Sasirangan industry $\left(X_{1.2 .2}\right)$, the tight price competition among the Sasirangan industry $\left(X_{1.2 .3}\right)$, and product innovation carried out by each Sasirangan industry $\left(X_{1.2 .4}\right)$. The results of the measurement model show all items are valid and significant at $\alpha 0.05$. The "tight product quality competition among the Sasirangan industry $\left(\mathrm{X}_{1.2 .1}\right)$ " has the highest factor loading of 0.823 ; it is considered as the best representation of competition intensity. The contribution of other items seen from the loading factor is promotional strategies $\left(X_{1.2 .2}\right)$ of 0.779 , price competition $\left(\mathrm{X}_{1.2 .3}\right)$ of 0.760 , and product innovation $\left(\mathrm{X}_{1.2 .4}\right)$ of 0.661 .

The two (2) indicators of environmental dynamics (X1) are valid. Based on the loading factor, the item that contributes the most for environmental uncertainty is on "products made by other companies become an alternative for consumers" $\left(\mathrm{X}_{1.1 .2}\right)$, with a loading value of 0.851. For competition intensity, the item that contributes the most is "the tight competition of product quality among the Sasirangan industry" $\left(\mathrm{X}_{1.2 .1}\right)$, with a loading value of 0.823 .

The variable of management capabilities $\left(X_{2}\right)$ is measured by four (4) indicators, namely planning $\left(X_{2.1}\right)$, organizing $\left(X_{2.2}\right)$, directing $\left(X_{2.3}\right)$, and monitoring $\left(X_{2.4}\right)$. Each indicator is developed into several items.

Table 15 - The Measurement Model for Planning $\left(\mathrm{X}_{2.1}\right)$

\begin{tabular}{|c|c|c|c|c|c|c|}
\hline \multirow{2}{*}{ Item } & \multicolumn{3}{|c|}{ Loading } & \multicolumn{3}{c|}{ Weight } \\
\cline { 2 - 8 } & Estimate & SE & CR & Estimate & SE & CR \\
\hline $\mathrm{X}_{\text {.2.1.1 }}$ & 0.876 & 0.020 & $43.93^{x}$ & 0.607 & 0.028 & $21.37^{x}$ \\
\hline $\mathrm{X}_{\text {.2.1.2 }}$ & 0.848 & 0.012 & $68.58^{x}$ & 0.552 & 0.034 & $16.29^{x}$ \\
\hline
\end{tabular}

The planning indicator is measured by 2 (two) items, namely being able to plan a strategy $\left(X_{2.1 .1}\right)$ and making decisions without the help of others $\left(X_{2.1 .2}\right)$. The results of the measurement model show that the items are valid and significant at $\alpha 0.05$. Both items are considered dominant in reflecting planning because the loading value is not much different, at 0.876 and 0.848 .

The second indicator of management capabilities (X2) is organizing measured using 2 (two) items, namely distributing work well to employees $\left(\mathrm{X}_{2.2 .1}\right)$ and building a reliable work team $\left(\mathrm{X}_{2.2 .2}\right)$. The results of the measurement model for this indicator show both items are valid and significant at $\alpha 0.05$. Both items are considered dominant in reflecting organizing because the loading value is not different, at 0.858 and 0.865 . 
Table 16 - The Measurement Model for Organizing $\left(X_{2.2}\right)$

\begin{tabular}{|c|c|c|c|c|c|c|}
\hline \multirow{2}{*}{ Item } & \multicolumn{3}{|c|}{ Loading } & \multicolumn{3}{c|}{ Weight } \\
\cline { 2 - 7 } & Estimate & SE & CR & Estimate & SE & CR \\
\hline$X_{\text {X.2.2.1 }}$ & 0.858 & 0.024 & $35.88^{*}$ & 0.574 & 0.005 & $124.55^{*}$ \\
\hline$X_{\text {X.2.2.2 }}$ & 0.865 & 0.010 & $90.25^{*}$ & 0.587 & 0.027 & $21.97^{*}$ \\
\hline
\end{tabular}

Table 17 - The Measurement Model for Directing $\left(\mathrm{X}_{2.3}\right)$

\begin{tabular}{|c|c|c|c|c|c|c|}
\hline \multirow{2}{*}{ Item } & \multicolumn{3}{|c|}{ Loading } & \multicolumn{3}{c|}{ Weight } \\
\cline { 2 - 7 } & Estimate & SE & CR & Estimate & SE & CR \\
\hline $\mathrm{X}_{\text {.2.3.1 }}$ & 0.875 & 0.023 & $37.9^{*}$ & 0.519 & 0.022 & $23.7^{*}$ \\
\hline $\mathrm{X}_{\text {.2.3.2 }}$ & 0.908 & 0.000 & - & 0.601 & 0.035 & $17.19^{*}$ \\
\hline
\end{tabular}

The third indicator of management capabilities (X2) is directing measured using 2 (two) items, namely communicating well with employees $\left(X_{2.3 .1}\right)$ and completing the work on time $\left(\mathrm{X}_{2.3 .2}\right)$. The results of the measurement model show both items are valid and significant at $\alpha$ 0.05. The "completing the work on time $\left(X_{2.3 .2}\right)$ " has the highest factor loading of 0.908 ; it is considered as the best representation of directing. The item "communicating well with employees (x2.3.1)" has a loading value of 0.875 .

Table 18 - The Measurement Model for Monitoring $\left(\mathrm{X}_{.2 .4}\right)$

\begin{tabular}{|c|c|c|c|c|c|c|}
\hline \multirow{2}{*}{ Item } & \multicolumn{3}{|c|}{ Loading } & \multicolumn{3}{c|}{ Weight } \\
\cline { 2 - 7 } & Estimate & SE & CR & Estimate & SE & CR \\
\hline $\mathrm{X}_{\text {.2.4.1 }}$ & 0.886 & 0.007 & $121.39^{*}$ & 0.576 & 0.030 & $18.96^{*}$ \\
\hline $\mathrm{X}_{\text {.2.4.2 }}$ & 0.878 & 0.023 & $37.37^{*}$ & 0.557 & 0.011 & $51.0^{*}$ \\
\hline
\end{tabular}

The fourth indicator of management capabilities (X2) is monitoring measured using 2 (two) items, namely making changes towards work in order to achieve better corporate goals $\left(X_{2.4 .1}\right)$ and being able to resolve conflicts that occur between the company and employees and with customers $\left(X_{2.4 .2}\right)$. The results of the measurement model show both items are valid and significant at $\alpha 0.05$. Both items are considered dominant in reflecting organizing because the loading value is not much different, at 0.886 and 0.878 .

The four (4) indicators forming management capabilities (X2) are valid. Based on the loading factor, the item that contributes the most for directing is "completing the work on time" $\left(X_{2.3 .2}\right)$ with a value of 0.908 ; for supervision, the item that contributes the most is "making changes towards work in order to achieve better company goals" $\left(\mathrm{X}_{2.4 .1}\right)$ with a value of 0.886 ; for planning, the item that contributes the most is "being able to plan a strategy" $\left(X_{2.1 .1}\right)$ with a value of 0.876 ; and for organizing, the item that contributes the most is "building a reliable work team" $\left(X_{2.2 .2}\right)$ with a value of 0.865 . Among the four indicators, the highest contribution for management capabilities (X2) is directing and the weakest is organizing.

Business strategies in this study are defined as the strategic efforts undertaken by ISM entrepreneurs to be able to compete and achieve business goals. The indicators used to measure the strategies $(X 3)$ are Low Cost Strategy Indicator $\left(X_{3.1}\right)$, Differentiation Strategy $\left(X_{3.2}\right)$, and Focus Strategy $\left(X_{3.3}\right)$. Each indicator is then developed into several items.

Table 19 - The Measurement Model for the Low Cost Stratgey $\left(\mathrm{X}_{3.1}\right)$

\begin{tabular}{|c|c|c|c|c|c|c|}
\hline \multirow{2}{*}{ Item } & \multicolumn{3}{|c|}{ Loading } & \multicolumn{3}{c|}{ Weight } \\
\cline { 2 - 7 } & Estimate & SE & CR & Estimate & SE & CR \\
\hline$X_{3} .1 .1$ & 0.923 & 0.024 & $38.27^{*}$ & 0.541 & 0.014 & $37.74^{*}$ \\
\hline$X_{3.1 .2}$ & 0.910 & 0.011 & $83.35^{*}$ & 0.494 & 0.035 & $14.22^{*}$ \\
\hline$X 3.1 .3$ & 0.309 & 0.015 & $20.64^{*}$ & 0.166 & 0.007 & $22.28^{*}$ \\
\hline
\end{tabular}

The low cost strategy is measured by 3 (three) items, namely maintaining the production continuity by maintaining the availability of raw materials and supporting materials 
$\left(X_{3.1 .1}\right)$, optimizing the existing tools and facilities $\left(X_{3.1 .2}\right)$, and making costs lower from competitors $\left(X_{3.1 .3}\right)$. The results of the measurement model show all items valid and significant at $\alpha$ 0.05. The item "maintaining the continuity of production" $\left(\mathrm{X}_{3.1 .1}\right)$ and "optimizing the existing tools and facilities" $\left(X_{3.1 .2}\right)$ are considered dominant in reflecting the low cost strategy as they have the highest loading values, at 0.923 and 0.910 . The item "making costs lower than competitors" $\left(\mathrm{X}_{3.1 .4}\right)$ is the weakest item with a loading value of 0.309 .

Table 20 - The Measurement Model for the Differentiation Strategy $\left(X_{3.2}\right)$

\begin{tabular}{|c|c|c|c|c|c|c|}
\hline \multirow{2}{*}{ Item } & \multicolumn{3}{|c|}{ Loading } & \multicolumn{3}{c|}{ Weight } \\
\cline { 2 - 7 } & Estimate & SE & CR & Estimate & SE & CR \\
\hline $\mathrm{X} 3.2 .1$ & 0.830 & 0.010 & $79.16^{*}$ & 0.360 & 0.044 & $8.18^{*}$ \\
\hline $\mathrm{X} 3.2 .2$ & 0.865 & 0.003 & $293.94^{*}$ & 0.343 & 0.002 & $179.46^{*}$ \\
\hline $\mathrm{X} 3.2 .3$ & 0.816 & 0.062 & $13.17^{*}$ & 0.295 & 0.016 & $18.04^{*}$ \\
\hline $\mathrm{X} 3.2 .4$ & 0.634 & 0.021 & $30.62^{*}$ & 0.260 & 0.006 & $43.44^{*}$ \\
\hline
\end{tabular}

The second indicator for business strategies (X3) is differentiation (X3.2) measured using 4 (four) items, namely developing a unique Sasirangan motif with distinctive characteristics from competing products $\left(X_{3.2 .1}\right)$, improving the quality to create a competitive advantage $\left(\mathrm{X}_{3.2 .2}\right)$, making Sasirangan products based on market segments (upper middle or lower middle class) $\left(\mathrm{X}_{3.2 .3}\right)$, and making custom colors or motifs to provide better service for customers $\left(X_{3.2 .4}\right)$.The results of the measurement model show all items valid and significant at $\alpha$ 0.05.The item "improving quality for competitive advantages" $\left(X_{3.2 .2}\right)$ has the highest factor loading of 0.865 ; it is considered dominant in reflecting the differentiation indicator. The loading values of other items are 0.830 for "developing a unique motif" $\left(X_{3.2 .1}\right), 0.816$ for "making products based on market segments" $\left(\mathrm{X}_{3.2 .3}\right)$, and 0.634 for "providing custom orders" $\left(\mathrm{X}_{3.2 .4}\right)$.

Table 21 - The Measurement Model for the Focus Strategy $\left(X_{3.3}\right)$

\begin{tabular}{|c|c|c|c|c|c|c|}
\hline \multirow{2}{*}{ Item } & \multicolumn{3}{|c|}{ Loading } & \multicolumn{3}{c|}{ Weight } \\
\cline { 2 - 8 } & Estimate & SE & CR & Estimate & SE & CR \\
\hline X3.3.1 & 0.867 & 0.034 & $25.16^{*}$ & 0.360 & 0.045 & $8.06^{*}$ \\
\hline X3.3.2 & 0.937 & 0.017 & $56.58^{*}$ & 0.373 & 0.025 & $14.67^{*}$ \\
\hline X3.3.3 & 0.925 & 0.011 & $82.0^{*}$ & 0.366 & 0.015 & $23.95^{*}$ \\
\hline
\end{tabular}

The third indicator for business strategies (X3) is the focus strategy (X3.3), which is measured by 3 (three) items, namely selling only certain products $\left(X_{3.3 .1}\right)$, selling only to certain groups $\left(X_{3.3 .2}\right)$, and selling only to certain customer segments $\left(X_{3.3 .3}\right)$. The results of the measurement model for this indicator show all items are valid and significant at $\alpha 0.05$. The item "selling only to certain groups" $\left(X_{3.3 .2}\right)$ has the highest loading value of 0.937 ; it is considered dominant in reflecting the focus strategy. The loading value of other items is 0.925 for "selling to certain customer segments" $\left(X_{3.3 .3}\right)$ and 0.867 for "selling only certain products" $\left(\mathrm{X}_{3.3 .1}\right)$.

The three (3) indicators for business strategies (X3) are valid. Based on the loading factor, the item that contributes the most for the low cost strategy is "maintaining the production continuity by maintaining the availability of raw and supporting materials" $\left(\mathrm{X}_{3.1 .1}\right)$ with a value of 0.923 ; for the differentiation strategy is "improving quality for competitive advantages" $\left(X_{3.2 .2}\right)$ with a value of 0.865 ; and for the focus strategy is "selling only to certain groups" $\left(X_{3.3 .2}\right)$ with a value of 0.937 . Among the three (3) indicators, the highest contribution for business strategies (X3) is the focus strategy and the weakest is differentiation.

The performance of SMls in this study is interpreted as the level of achievement of the company in a certain period; this is very decisive in the development of the company. The indicators used to measure the performance $(Y 1)$ are sales growth $\left(Y_{1.1}\right)$, profit growth $\left(Y_{1.2}\right)$, and capital growth $\left(\mathrm{Y}_{1.3}\right)$. Each indicator is developed into several items. 
Table 22 - The Measurement Model for Sales Growth $\left(Y_{1.1}\right)$

\begin{tabular}{|c|c|c|c|c|c|c|}
\hline \multirow{2}{*}{ Item } & \multicolumn{3}{|c|}{ Loading } & \multicolumn{3}{c|}{ Weight } \\
\cline { 2 - 7 } & Estimate & SE & CR & Estimate & SE & CR \\
\hline Y1.1.1 & 0.928 & 0.001 & $1429.52^{*}$ & 0.560 & 0.007 & $76.57^{*}$ \\
\hline Y1.1.2 & 0.917 & 0.004 & $212.54^{*}$ & 0.524 & 0.005 & $116.17^{*}$ \\
\hline
\end{tabular}

The sales growth indicator is measured by 2 (two) items, namely an increase in sales (turnover) from year to year $\left(Y_{1.1 .1}\right)$ and an increase in sales (turnover) followed by an increase in production $\left(Y_{1.1 .2}\right)$. The results of the measurement model show that all items are valid and significant at $\alpha 0.05$. The two items are considered dominant in reflecting sales growth, as the estimated value is 0.928 and 0.917 .

Table 23 - The Measurement Model for Profit Growth $\left(\mathrm{Y}_{1.2}\right)$

\begin{tabular}{|c|c|c|c|c|c|c|}
\hline \multirow{2}{*}{ Item } & \multicolumn{3}{|c|}{ Loading } & \multicolumn{3}{c|}{ Weight } \\
\cline { 2 - 7 } & Estimate & SE & CR & Estimate & SE & CR \\
\hline Y1.2.1 & 0.914 & 0.025 & $36.18^{*}$ & 0.624 & 0.022 & $27.76^{*}$ \\
\hline Y1.2.2 & 0.862 & 0.012 & $74.11^{*}$ & 0.499 & 0.049 & $10.22^{*}$ \\
\hline
\end{tabular}

The second indicator for performance $(Y 1)$ is profit growth $\left(Y_{1.2}\right)$ measured using 2 (two) items, namely an increase in profit $\left(Y_{1.2 .1}\right)$ and the increase in profit is higher than the increase in capital used $\left(Y_{1.2 .2}\right)$. The measurement model results obtained for this indicator show all items are valid and significant at a 0.05 . The item "the increase in profit is higher than the increase in capital used" $\left(Y_{1.2 .1}\right)$ has the highest loading value of 0.914 ; it is considered dominant in reflecting the profit growth indicator. The loading value for the other item $\left(\mathrm{Y}_{1.2 .2}\right)$ is 0.862 .

Table 24 - The Measurement Model for Capital Growth $\left(\mathrm{Y}_{1.3}\right)$

\begin{tabular}{|c|c|c|c|c|c|c|}
\hline \multirow{2}{*}{ Item } & \multicolumn{3}{|c|}{ Loading } & \multicolumn{3}{c|}{ Weight } \\
\cline { 2 - 7 } & Estimate & SE & CR & Estimate & SE & CR \\
\hline$Y_{\text {Y.1.3.1 }}$ & 0.854 & 0.029 & $28.96^{*}$ & 0.578 & 0.022 & $26.15^{*}$ \\
\hline$Y_{\text {Y.1.3.2 }}$ & 0.859 & 0.030 & $28.25^{*}$ & 0.589 & 0.017 & $35.05^{*}$ \\
\hline
\end{tabular}

The third indicator for performance $(\mathrm{Y} 1)$ is capital growth $\left(\mathrm{Y}_{1.3}\right)$, which is measured using 2 (two) items, namely increasing the amount of capital from year to year $\left(\mathrm{Y}_{1.3 .1}\right)$ and the need for additional capital for business development $\left(\mathrm{Y}_{1.3 .2}\right)$. The results of the measurement model show all items are valid and significant at $\alpha 0.05$. Both items are considered dominant in reflecting capital growth considering the loading values of 0.854 and 0.859 .

The items forming indicators performance (Y1) are valid. Based on the loading factor, the items that contributes the most for sales growth are "an increase in sales (turnover) from year to year" $\left(\mathrm{Y}_{1.1 .1}\right)$ and "an increase in sales (turnover) followed by an increase in production" $\left(Y_{1.1 .2}\right)$, as the loading value of these items is 0.928 and 0.917 . The item that contributes the most for profit growth is "the increase in profit is higher than the increase in capital used" $\left(Y_{1.2 .1}\right)$ with a loading value of 0.914 . The item that contributes the most for capital growth is "the increase in profit is higher than the increase in capital used" $\left(Y_{1.3 .2}\right)$ with a loading value of 0.859 . Among the three (3) indicators, the highest contribution for performance $(\mathrm{Y} 1)$ is profit growth and the weakest is capital growth.

The Results of Hypothesis Testingю Based on empirical data analysis, hypothesis testing was done using the GeSCA Program. The test results can be seen in Table 25.

Environmental dynamics have a significant positive effect on SMI performance. GeSCA results in Table 25 show a path coefficient of $0.073^{*}$ and CR of $2.64^{*}$ (significant, positive sign). These results indicate that good environment dynamics encourages better performance of SMls. Environmental uncertainty and competition intensity as indicators 
forming environmental dynamics can be used directly to increase sales growth, profit growth, and capital growth as a form of SMI performance.

Table 25 - The Results of Hypothesis Testing

\begin{tabular}{|c|c|c|c|c|c|}
\hline \multirow{2}{*}{ No } & \multirow{2}{*}{ The Relationship of Variables } & \multicolumn{4}{|c|}{ Direct Effect } \\
\cline { 3 - 6 } & & Estimate & SE & CR & Note \\
\hline 1 & Environ mental Dynamics-> Performance & 0.073 & 0.028 & 2.64 & Significant \\
\hline 2 & Management Capabilities-> Performance & 0.029 & 0.007 & 4.28 & Significant \\
\hline 3 & Business Strategies-> Performance & 0.571 & 0.032 & $17.99^{*}$ & Significant \\
\hline
\end{tabular}

This study supports Bisbe and Malaguenu (2012) by taking a sample of 267 respondents from medium and large companies in Spain. Data is analyzed using SPSS Macro. Their findings indicate that environmental dynamics have a significant effect on organizational performance. Furthermore, the results of the present study also support the results of Jiao et al. (2013) by taking a sample of 115 respondents. Data is analyzed using structural equation models (SEM). Jiao et al. (2013) confirm that environmental dynamics have a significant impact on the performance of new businesses; this study concludes that a dynamic ability is more effective for organizational changes at a high degree of environmental dynamics. Bastian and Muchlish (2012) and Mohd et al. (2013) show that environmental dynamics have a significant effect on organizational performance. Nandakumar et al. (2010) suggest that environmental dynamics affect business performance mediated by business strategies. The results of this study are contradictory to Azadegan et al. (2013), that environmental dynamics have no significant effect on performance.

The results of this study support Nisjar and Wanardi (1997) that complex environmental influences can affect the performance of an organization. Furthermore, Mohd et al. (2013) argue that external environment has a direct effect on the performance of the company without looking at the choices of the strategies carried out by the company; this can mean that the external environment can hinder and/or directly support performance. Hashim et al. (2001) affirm that power outside the company influencing performance is a dynamism variable, which identifies the environmental uncertainty. Environmental influences other than uncertainty can also take the form of competition intensity.

Management capabilities have a significant positive effect on SMI performance. GeSCA results in table 25 show a path coefficient of $0.029^{*}$ and CR of $4.28^{*}$ (significant, positive sign). These indicate that management capabilities of SMI owners can directly improve performance. This suggests that the implementation of management capabilities, which include planning, organizing, directing, and monitoring, can be used directly to increase sales growth, profit growth, and capital growth as a form of SMI performance. The most dominant form of management capabilities is directing on completing the work on time. Then, the variable forming SMI performance that contributes the most is sales growth, through an increase in turnover from year to year.

The findings support the results of previous studies by Akgun et al. (2008), taking a sample of 356 respondents from 112 companies, involving managers and employees from various companies operating in Istanbul. Data is analyzed by a hierarchical regression, and results show that emotional abilities have a significant and positive effect on financial performance and organizational effectiveness. Furthermore, Man and Wafa (2008), taking a sample of 100 SMEs in the manufacturing sector in Malaysia, using structured questionnaires and interviews with SME owners, multiple regression and One-Way ANOVA analysis, reveal that management capabilities have a positive and significant effect on the performance SMEs. The findings of this study are also in line with Suci (2009) that management capabilities have a significant positive effect on performance; in other words, sufficient management capabilities can determine the success of SMI performance. The findings are also supported by several other studies such as Wai and Kuan (2011), Chi et al. (2011), Hsu (2012), Fening (2012), and Dani et al. (2013), that management skills directly affect performance. The results of this study contradict the findings by Ursic and Mulej 
(2005), that management capabilities directly have no significant effect on business performance.

The results of this study support the theory of Tidd and Pavitt (1998), that management capabilities are very important in small, medium, and large-scale industries, where each requires management activities to coordinate the skills of workers as well as coordination of resources of the company. The role of the leaders or owners of the company is to understand and carry out management functions as the main thing to achieve success. Management is the achievement of organizational goals in an effective and efficient way through planning, organizing, directing, and controlling organizational resources (Daft, 2006).

Business strategies have a significant and direct positive effect on performance. The result of GeSCA in Table 25 shows a path coefficient of $0.571^{*}$ and CR of 17.99* (significant). This means that the implementation of the business strategy by SMI owners can improve performance. This proves that the more appropriate the low cost strategy, differentiation, and focus strategy, as indicators of business strategies, the more sales growth, profit growth, and capital growth will be.

This finding supports the theories of Pierce II and Robinson (2007) defining strategic management as a set of decisions and actions that result in the formulation and implementation of plans designed to achieve company goals. Jauck and Glueck (1988) assert that the flow of strategic management processes shapes the flow of decisions and actions that lead to the formation of effective strategies to achieve organizational goals. This study supports the findings of Parnell (2010) who examines the relationship between membership of strategic groups and performance of retailers in the United States in the complexity of strategy-performance relationship. Parnell takes a sample of 277 retail traders in the Midwestern city of the United States and uses a regression method for the data analysis; the findings indicate that business strategies have a positive and significant effect on business performance in a relatively short period of time and high business performance results in positive profits in the long term. Acquaah (2013) also proves that business strategies affect the performance of family business organizations.

Some other research including Man and Wafa (2008), Bordean et al. (2010), Hsu (2012), Li and Tan (2013), and Mohd et al. (2013) state that business strategies have a significant effect on performance. In contrary, Xiaoying et al. (2008) and Zhi and Jintong (2012) find that business strategies do not affect performance.

\section{CONCLUSION}

Environmental dynamics have a significant positive effect on SMI performance. These indicate that the dynamics of environment encourage better SMI performance. Environmental uncertainty and competition intensity as indicators of environmental dynamics can be used directly to increase sales growth, profit growth, and capital growth as indicators of SMI performance.

Management capabilities have a significant positive effect on SMI performance. These indicate that the management capabilities of the SMI owners can directly improve SMI performance. This finding suggests that management capabilities, which include planning, organizing, directing, and monitoring, can be used directly to increase sales growth, profit growth, and capital growth as indicators of SMI performance.

Business strategies have a significant and direct positive effect on SMI performance; this means that the business strategies carried out by SMI owner can improve the SMI performance. This proves that appropriate implementation of low cost strategies, differentiation, and focus strategies, as indicators of business strategies, will further increase sales growth, profit growth, and capital growth as indicators of SMI performance.

Recommendations:

- Further studies are advised to include more areas as the study site and more respondents considering that the SMI actors are increasing and spread throughout the cities and regencies in South Kalimantan; 
- Owners of Sasirangan SMI should improve management capabilities as these will help to formulate the right business strategy in such dynamic environment;

- Owners of Sasirangan SMI should improve the quality of Sasirangan products, by choosing quality raw and coloring materials, as well as innovative motif designs, so the products can be accepted by local and international markets or consumers.

\section{REFERENCES}

1. Anshoff, I. 1990. The New Corporate Strategy, McGraw-Hill, New York.

2. Akgun, Ali E., Halit Keskin and John Byrne. 2008. "The Moderating Role of Environmental Dynamism Between Firm Emotional Capability and Performance", Journal of Organizational Change Management, Vol. 21, No. 2, Emerald Group Publishing Limited organizational capabilities or competencies, pp. 230-252.

3. Azwar, S., 2013, Penyusunan Skala Psikologi, Edisi 2, Cetakan IV, Pustaka Pelajar Offset, Yogyakarta.

4. Bastian, Alvin, Muchlish Munawar. 2012. "Perceived Environment Uncertainty, Business Strategy, Performance Measurement Systems and Organizational Performance", Procedia-Social and Behaviour Science No.65, pp.787-792.

5. Bastian, Alvin, Muchlish Munawar. 2012. "Perceived Environment Uncertainty, Business Strategy, Performance Measurement Systems and Organizational Performance", Procedia-Social and Behaviour Science No.65, pp.787-792.

6. Bisbea, Josep, Malagueno, Ricardo. 2012. "Using Strategic Performance Measurement Systems for Strategy Formulation: Does It Work in Dynamic Environments?", Managing Accounting Research No.23, pp.296-311.

7. Brooks, lan dan Jamie Weatherston. 2000. The Business Environment: Challenges and Changes $2^{\text {nd }}$ edition. Prentice-Hall: Harlow

8. Boyd, B.K. and Fulk. J., 1996. Executive Scanning and Perceived Uncertainty: A Multidimentional Model, Journal of Management, Vol. 22, pp.1-21

9. Chi, Kuang Hsin, Huery Ren Yeh, and Yu Ling Chen. 2011. "The Mediating Effect of Knowledge Management on Customer Orientation and Job Performance of Sales people".

10. Cohen, J., 1992, Statistical Power Analysis, Current Directions in Psychological Science, Vol. 1, No. 3, h.98 - 101, Sage Publications, Inc.

11. Cresswell, John W., 2009, Reseach Design: Qualitative, Quantitative and Mixed Methode Approaches. Third Edition, Sage Publication Inc., California.

12. Dani, Ibrahim, Idrus, M.S., Nimran, Umar, Sudiro, Achmad, 2013. "Business Strategy Role as Mediation of Management Capability and Orientation of Entrepreneurship on Business Performance (A Study on Micro and Small Scale Seaweed Business in Takalar District, South Sulawesi Province). Journal of Management Reseach ISSN 1941-899x, Vol.5, No.1

13. Edward, M. 1994, Non Govermental Organizations: Performance and AccountabilityBeyond the Magic Bullet, Earthscan, London

14. Efferin, Sujoko and Bonnie Soeherman. 2010. Seni Perang Sun Zi dan Sistem Pengendalian Manajemen: Filosofi dan Aplikasi. PT Gramedia: Jakarta.

15. Efferin, Sujoko dan Arthur Handrian. 2010. Saling Peran antara Budgeting, Dinamika Lingkungan Bisnis, dan Konflik Internal: Studi Interpretif. Manajemen dan Bisnis, Vol 9 No 2 hal 161-187.

16. Fening, Fred Appiah. 2012, "Impact of Quality Management Practices on the Performance and Growth of Small and Medium Sized Enterprises (Smes) in Ghana", International Journal of Business and Social Science Vol. 3 No. 13; July 2012.

17. Hashim M K, S. A. Wafa and M. Sulaiman. 2001. "Testing Environment as Mediator Between Business Strategy-Performance Relationship: A Study of Malaysian SMEs", $46^{\text {th }}$ ICSB World Conference - jan 17-20 2001, Taipei, Taiwan. 
18. Hunger. J. David., and Wheelen., Thomas I. (2003). Manajemen Strategis, Penerbit Andi, Yogyakarta. Infokop Nomor 25 Tahun XX.

19. Hsu, Shu Hung, 2012. "Effects of Competitive Strategy, Knowledge Management and EBusiness Adoption on Performance". The Journal of Human Resource and Adult Learning, Vol. 8, Num. 2.

20. Jauch L.R, and Glueck W.F, 1988, Business Policy and Strategic Management, McGraw Hill, New York.

21. Jiao, Hao, Ilan Alon, Chun Kwong Koo and Yu Cui. 2013. "When Should Organizational Change be Implemented? The Moderating Effect of Environmental Dynamism Between Dynamic Capabilities and New Venture Performance", Journal of Engineering and Technology Management, Vol.30, pp.188-205.

22. Lumpkin, G.T. and Dess, G.G., 1996, Clarifying the Entrepreneurial Orientation Construct and Linking it to Performance , Academy of Management Review., Vol 21. No. pp.135172.

23. Lumpkin, Marlyn L. Taylor, 2005, Strategc Management: Creating Competitive Advantages, Published by MCGraw-Hill/Irwin.

24. Lawrence, Anne T. and James Weber. 2011. Business and Society: Stakeholders, Ethics, Public Policy. McGraw Hill: New York.

25. Li, Yan and Tan Chuan-Hoo 2013."Matching Busines Strategy and CIO Characteristics: The Impact on Organizational Performance", Journal of Business Research Vol.66, pp.248-259.

26. Maskur. 2018. The Influence of Entrepreneurial Orientation on Business Strategy and Performance of Medium-Small Scale Sasirangan Industries in South Kalimantan Province. Russian Journal of Agricultural and Socioeconomic Sciences. pp. 208-216. Crossref DOI: 10.18551/rjoas.2018-02.23

27. Mahmud, Ariati Anomsari. 2011. Analisis pengaruh orientasi kewirausahaan kemampuan manajemen dan strategi bisnis dalam peningkatan kinerja perusahaan ( studi pada usaha kecil menengah di kawasan usaha Barito semarang. Jurnal semantic

28. Man, Mandy Mok Kim and Wafa Syed Azizi. 2008. "The Relationship Between Distinctive Capabilities, Innovativeness, Strategy Types and the Performance of Small and Medium: Size Enterprises (SMEs) on Malaysian Manufacturing Sector", The Journal of American Academy of Business vol.13.

29. Mohd, Wael, Subhi Idris, Raed A. Momani. 2013. "Impact of Environmental Dynamism on Marketing Strategy Comprehensiveness and Organizational Performance", International Journal of Business an Management; Vol.8 No.9.

30. Miles M.P., Jeffery G. Covin and Michael Heeley B. 2000. "The Relationship between Environmental Dynamism and Small Firm Structure, Strategy, and Performance”, Journal of Marketing Theory and Practice, Spring, pp.63-74.

31. Nandakumar M. K., Abby Ghobadian and Nicholas O'Regan. 2010. "Business-level Strategy and Performance: The Moderating Effects of Environment and Structure", Management Decision Vol 48 No 6, Emerald Group Publishing Limited, pp.907-939.

32. Nisjar, Karhi dan Winardi (1997), Manajemen Strategik, Penerbit CV. Mandar Maju.

33. Nur, Nofal. 2014. Entrepreneurship Orientation,Market Orientation,Business Strategy, Management Capabilities On Business Performance;Study At Small And Medium Enterprise Printing In Kendari. International Journal of Business and Management Invention. Volume 3 Issue 12

34. Parnell, John A., 2010. "Strategic Clarity, Business Strategy and Performance, Journal of Strategy and Management", Vol 3, No 4, Emerald Group Publishing Limited, pp.304-324.

35. Parsian, N., Dunning, T., 2009, Developing and Validating a Questionnaire to Measure Spiritually: A Psychometric Process, Global Journal of Health and Science, Vol. 1, No. 1, h.2-11.

36. Peters, R.D., 1998. Entrepreneurship, Fourth Editon, McGraw Hill Companies, Inc, NY.

37. Pearce II J.A., and Robinson Jr. R.B. 2007. Strategic Management Formulation, Implementation, and Control, $10^{\text {th }}$ ed. McGraw-Hill, Boston.

38. Porter E.M., 2005, Competitive Strategy, Collier Macmillan. Release: 1998 
39. Purnama, Chamdan and Subroto W.P. 2016.Competition Intensity, Uncertainty Environmental on the use of Information Technology and its Impact on Business Performance Small and Medium Enterprises.International Review of Management and Marketing.Vol. 6(4): 984-992

40. Surachman, Sumawihardja, 2002, Mengembangkan Keunggulan Barsaing Usaha Kecil dan Menengah Untuk Mencapai Posisi Pasar Yang Kuat dan Berkesinambungan dalam Era Global, Makalah Kuliah Kenangan dan Apresiasi, UNPAD, Bandung.

41. Sugiono, 2008, Metode Penelitian Bisnis, Cetakan Ke- dua Belas, Penerbit Alfabeta, Bandung.

42. Storey, D.J., 1994, Undestanding The Small Business Sector, London, Routledge. Strategies for Building a High-Profit Business, Publishing: AMACOM

43. Suci, Rahayu Puji, 2009, Peningkatan Kinerja melalui Orientasi Kewirausahaan, Kemampuan Manajemen, dan Strategi Bisnis, Jurnal Manajemen dan Kewirausahaan. Vol.11, No.1, Maret 2009, 46-58

44. Tidd, J., Bessant, J. and Pavitt, K., 1998, Managing Innovation- Integrating Technological, Market and Organizational Change, Hohn wiley and Sons, Chichester.

45. Usric, Dusko and Mulej, Matjaz, 2005. "Theory and Practice of management Concepts: Slovania's Experiences. The Journal of Management Development; ABI/INFORM Complete, pp. 856.

46. Wai, Peng Wong and Kuan, Yew Wong, 2011. "Supply Chain Management, Knowledge Management Capability, and Their Linkages Towards Firm Performance", Business Process Management Journal, vol 17, Num 6, Emerald Group Publishing Limited, pp.910-964.

47. Xiaoying, Dong, Liu Qianqian and Yin Dezhi. 2008. "Business Performance, Business Strategy, and Information System Strategic Alignment: An Empirical Study on Chinese Firms", The Journal of Human Resource and Adult Learning, Vol.8, Num. 2.

48. Zhi, Tang and Jintong, Tang, 2012" Entrepreneurial orientation and SME performance in China's changing environment: The moderating effects of strategies". Springer Science Business Media. 